\title{
Kıbrıs Türk Toplumunda Kumar Alt Kültürü
}

\section{Gambling Subculture in the Turkish Cypriot Community}

\author{
Ruken Macit ${ }^{1}$ (D) \\ 1. Harran Üniversitesi Fen Edebiyat Fakültesi, Sosyoloji Bölümü, Şanlıurfa, Türkiye
}

\begin{abstract}
Objective: Many studies reveal the prevalence of gambling addiction among Cypriots. The prevalence of gambling behavior (PPK) in the Turkish Cypriot community stands out as one of the four societies with the highest gambling addiction in the world with the "extremely high" classification. This study aims the historical dimension of the gambling culture in the Turkish Cypriot community and how gambling addiction has been shaped as a subculture in casinos are analyzed.

Method: Semi structured interviews were conducted with 20 gamblers and one casino manager living in Cyprus. Qualitative research method was used.

Results: The meaning of gambling for gamblers, casino routines (how often they go to the casino, who they go with, what types of gambling they play, their superstitions in gambling) and gamblers' dreams have been obtained.

Conclusion: Contrary to popular belief, the meaning of gambling for gamblers is primarly "pleasure and relaxation. The desire to make Money is seen as the second or third goal. Gambling behavior in the Turkish Cypriot community has gone beyond being an activity aimed at socializing and having fun. It has reached the advanced stages of gambling addiction. The political, social and economic structure of TRNC is the most important factor.
\end{abstract}

Keywords: Gambling addiction, subculture, casino, TRNC

Öz

Amaç: Kıbrıs Türk toplumu 'aşıı yüksek' kumar oynama davranış yaygınlığı (PPK) ile dünyada kumar bağımılıı̆ıııın en fazla olduğu dört toplumdan biri olarak dikkat çekmektedir. Bu çalışmanın amacı Kıbrıs Türk toplumundaki kumar kültürünün tarihsel boyutunu ve kumar bağımlılı̆ının kumarhanelerde bir alt kültür olarak olarak nasıl şekillendiğini analiz etmektir.

Yöntem: KKTC'nin Girne şehrinde yaşayan 20 kumarcı ve 1 Kumarhane Müdürü ile yarı yapılandırımış görüşmeler yapılımışır. Araştırma çerçevesinde nitel araştırma yöntemi kullanılmıştır.

Bulgular: Kumarın kumarclar için anlamı, kumarhane rutinleri (kumarhaneye ne kadar sıklıkla gittikleri, kimlerle gittikleri, hangi kumar türlerini oynadıkları, kumardaki batı inançları) ve kumarcıların hayalleri ile ilgili dikkat çekici bulgular elde edilmiştir.

Sonuç: Toplumdaki genel kanının aksine kumarcılar için kumarın anlamı öncelikle "zevk alma ve rahatlama"dır. Para kazanma isteği ikinci ya da üçüncü amaç olarak görülmektedir. Kıbrıs Türk toplumunda kumar oynama davranışı sosyalleşme ve eğlenme amacıyla yapılan bir etkinlik olmanın çok ötesine geçerek kumar bağımlılı̆ının ileri aşamalarına ulaşmıştır. KKTC'nin siyasi, sosyal ve ekonomik yapısı bu sürecin şekillenmesindeki en önemli unsurdur.

Anahtar kelimeler: Kumar bağımlıı̆̆ı, alt kültür, kumarhane, KKTC 


\section{Giriş}

Yaşam düzenini bozmaya neden olacak şekilde ve sürekli bir biçimde kumar oynama davranışı kumar bağımılı̆̆ı kavramını açıklamaktadır. Kumar bağımlıı̆̆ı sadece bağımlı bireyi olumsuz etkileyen bir unsur değildir. Bağımlılar ile birlikte aileleri, çevresi genel olarak da toplum olumsuz etkilenmektedir. Bu nedenle, kumar bağımlılı̆ı toplumu etkileyen önemli sosyal problemlerden biridir. Kumar oynama davranışı sıfırdan dörde kadar derecelendirilen dört seviyede değerlendirilmektedir. Buna göre; 0 seviyesi hayatında hiç kumar oynamayanları isimlendirmek için kullanılır. Birinci seviye; sosyal ya da boş vakit oynayıcılarına karşlık gelir. Kumar oynayanların çok büyük bir bölümü bu seviyededir ve bu oynama hayatta herhangi bir problem oluşturmamaktadır İkinci seviye; kumar oynamaya bağlı bazı problemler yaşamaya başlayan kumar oynayanlara karşıllık gelir. Bu seviyedekiler için riskli kumar oynama, problemli kumar oynama tanımları da kullanıır. Üçüncü seviye; kumar oynamaya bağlı ciddi sorunlar yaşamaya başlayan kumarcılara karşılık gelir. Bu seviyedekiler genelde DSM'deki patolojik kumar tanı kriterlerini karşılarlar (1).

Kumar oynama üzerindeki kontrolün yitirilmesi sonucu kumar oynamayla planlandığından daha fazla vakit geçirilmesi ve kumar oynamanın sonlandırılamaması gibi deneyimler, literatürde patolojik/ problemli kumar oynama ya da kumar bağımlıı̆ı olarak tanımlanmaktadır (2;3). 1980 yılında Amerikan Psikiyatri Derneği (APA), kumar bağımlıı̆ııı ilk olarak "Patolojik Kumar Oynama" (PKO) olarak tanımlamış ancak bağımlıık sınıfına almamıştır. 2013 yılında ise "Madde ile İlişkili ve Bağımlılık Bozuklukları" kategorisinde "Madde ile ilişkili olmayan bozukluk" başlığı altında ele almıştır. Bunun nedeni olarak da kumar oynamada, aynı madde bağımlılığındaki gibi bilişsel, nörolojik, genetik ve davranışsal özelliklerin olduğu ve kumar oynama bozukluğu olanlarda madde bağımlılığı eş tanısının yüksek olduğu öne sürülmüştür (4).

Kumar bağımlılı̆ı ile ilgili yapılan çalışmalar dünyanın \%1'inin kumar bağımlılığından etkilendiğini göstermektedir. Dünyada problemli ve patolojik kumar oynamanın (PPK) yaygınlığı bölgeden bölgeye değişmektedir. Genel olarak en düşük problemli kumar oynama oranları Avrupa'da, orta derecede Kuzey Amerika-Avustralya'da ve en yüksek ise Asya'da bulunmaktadır. Asya'nın Hong Kong, Singapur ve Macau gibi bazı bölgelerinde patolojik kumar oynama oranları yüksek oranlarda ve yaklaşık \%2 olarak bildirilmiştir. Problemli kumar oynama oranlarının ergenler, yerli azınlık grupları ve göçmen topluluklar arasında daha yaygın olduğu görülmektedir. Dünyanın dört farklı yerli azınlık grubu olan Porto Riko'da Porto Rikolular, Yeni Zelanda'da Maoriler, Kuzey Dakota'da Amerikan yerlileri ve KKTC' de Kıbrıs Türk toplumunda 'aşırı yüksek' PPK oynama davranış yaygınlığı bulunmuştur. Dünyanın dört bölgesinde yaşayan bu etnik grupların sosyokültürel özelliklerinin birbirine benzediği görülmektedir (5). Çakıcı ve arkadaşları (5) bu dört grubun ortak özelliklerini kolonizasyon öyküsü, ekonomik sömürüye uğrama, sosyoekonomik dezavantajlar, düşük eğitim düzeyi ve yüksek işsizlik oranı olarak tanımlamıştır.

KKTC'nin İngiltere'nin uzun yıllar himayesi altında kalması, uluslararası tanınırlığının olmamasında kaynaklanan ambargolar ve sosyo-ekonomik bunalım bu gruplarla benzerlik göstermesine neden olmaktadır. Tarihsel sürece baktığımızda ise Kıbrıslı Türkler arasında eğlence amaçlı tombala gibi kumar türlerinin varlığı dikkat çekmektedir. Bu çalışmada Kıbrıs Türk toplumundaki kumar kültürünün tarihsel gelişimi ve bu süreçte kumar yaşamlarının bir alt kültür olarak olarak nasıl şekillendiği analiz edilmiştir. Bu bağlamda, ilk olarak kumar bağımlıı̆ı konusunda literatürde yapılan çalışmalar değerlendirilmiştir. İkinci olarak, Kıbrıs Türk toplumundaki kumar kültürünün tarihsel gelişimi ile birlikte kumarın kumarcılar için anlamı, kumarcıların kumarhane rutinleri (kumarhaneye ne kadar sıklıkla gittikleri, kimlerle gittikleri, hangi kumar türlerini oynadıkları, batı inançları) ve hayalleri analiz edilmiştir. Son olarak da, katılımcılardan elde edilen bulgular değerlendirilecektir. Kıbrıs toplumunda genellikle kumarhanelere "casino" denildiği için katılımcıların ifadelerinde kumarhane yerine casino terimi kullanılmıştır. Literatürde bağımlılık konusunda sayısız çalışma bulunmasına karşılık, bu çalışmaların çoğunluğu uyuşturucu madde bağımlılı̆ı (6-9) ya da son yıllarda ilgi gören internet bağımlılı̆ı (10-12) konusunda yapılan çalışmalardır. Özellikle sosyoloji alanında kumar bağımlıı̆ı konusunda yapılan çalışmalar oldukça azdır. Tarihsel süreçte, sosyologlar kumar dünyasılyla nadiren ilgilenmişlerdir. Bunun ilk örneklerinden biri Edward Devereux'dır. Devereux, yarış pisti ve oyuncu sayıları üzerine yaptığı bir çalısmada "umutsuzluk çemberi" olarak adlandırdığı şeyi 
inceleyen illk sosyologdur (13). Livingston ve Lesieur, günümüzde "patolojik kumarbazlar" olarak adlandırdığımız grubu sosyolojik olarak inceleyen araştırmacılardır. Çalışmasında Livingston, yarış pistlerinde ve Adsı Kumarbazlar toplantılarında sorunlu kumarbazları gözlemlemiştir. Her iki araştırmacı da "kompulsif" kumarı "kariyer" perspektifinden yorumlamıştır. Livingston, kumar bağımlılı̆ı üzerinde dururken, Lesieur'un odak noktası kumar bağımlılığından yasadışı faaliyetlere giden yollar üzerinedir $(14,15)$.

Günümüzde ise sosyolojik araştırmalar çoğunlukla kumar bağımlıı̆ının bireyin ailesi, arkadaşları, iş çevresi ve okul hayatına verdiği zararlar üzerine odaklanmaktadır (16-19). Bind "Işyerinde kumarla ilgili zarar ve suçu önlemek" adlı çalışmasında kumar bağımlılığının işte verimsizliğe ve devamsızlığa yol açtığını savunmuştur. Kumar oynamanın sürekli bir para intiyacına neden olduğu için işyerinden para veya mal hırsızıı̆ına bile neden olabileceği ifade edilmiş̧tir. Ayrıca, işyerinde kumarla ilgili zararları ve suçları önlemeye ve bunlara yanıt vermeye yönelik önlemler özetlenmektedir (18). Salonen ve arkadaşlarının "2016'da Finlandiya'da kumar oynamaya katılım, kumar alışkanlıkları, kumarla ilgili zararlar ve kumar reklamcılığına ilişkin görüşler" adlı makalesinde ise katılımcılar, tahmin edileceği üzere, kumardan önemli miktarda zarar görmüşlerdir. En sık karşılaşılan maddi zararlar ve duygusal/ psikolojik zararlardır. Bunun yanı sıra sağlık ve ilişkilerle ilgili gördükleri zararlarda oldukça fazladır (19).

Türkiye'de ise kumar çalışmaları denilince daha çok şans oyunları üzerine yapılan çalışmalar dikkat çekmektedir. Sağır ve Çabuk "Şans Oyunlarının Toplumun Beklentileri Üstüne Etkisi" adlı çalışmalarında, bireylerin şans oyunlarından beklentilerini açıklamaktadır (20). Üstün ise "At Yarışı Oynayanların Sosyalleşme Deneyimleri" adlı çalışmasında, ganyan bayilerinde bireylerin sosyalleşme örüntüleri betimlemektedir (21). Her iki çalışmada şans oyunu oynanan yerlerin bireyler için öncelikle bir sosyalleşme mekânı olduğu ve bahis oynamanın kazanç beklentisi ile hayata heyecan katma gibi intiyaçların karşılanmasının da bir yolu olabileceği sonucuna varmışlardır.

Literatürde kumar konusunda yapılan sosyolojik çalışmalar değerlendirildiğinde, bu çalışmalarda genellikle kumar kültürünün tarihsel boyutunun ve alt kültürel bir yapı olarak kumarcıların yaşamlarının göz ardı edildiği görülmektedir. Bu çalışmada bu eksiklik giderilerek Kıbrıs'taki "kumarcılar" bir alt kültür olarak ele alınacaktır. Kumarcılar için kumarın anlamı, kumar yaşamları ve hayalleri bu çerçevede açıklanacaktır.

\section{Yöntem}

\section{Örneklem}

Bu araştırmada, Kıbrıs Türk toplumunda kumar kültürünün tarihsel boyutu ve alt kültürel bir yapı olarak kumarcıların yaşamlarının kumarhanelerde nasıl şekillendiğini analiz etmek amaçlanmıştır. Bu bağlamda, KKTC'nin Girne şehrinde yaşayan 20 kumarcı ve 1 kumarhane müdürü ile yarı yapılandırılmış görüşme yapılmıştır. Bu görüşmeler 2020 yılı içinde tamamlanmıştır. Her bir katılımcı ile yapılan görüşme yaklaşık olarak bir saat sürmüştür.

\section{İşlem}

Araştırma verilerinin toplanması, Harran Üniversitesi yönetiminden araştırmanın yürütülebileceğine dair Etik Kurul Raporu (2020/59) ve katılımcılardan onay alınması ile başlandı. Araştırma çerçevesinde nitel araştırma yöntemi kullanılmıştır. Nitel teknikler araştırmacıların diğer insanların anlayış ve algılarından pay almalarına ve insanların günlük yaşamlarını nası yapılandırıp anlam verdiklerine olanak sağlamaktadır. Nitel teknikler kullanan araştırmacılar kişilerin kendileri ya da başkaları hakkında nasıl bilgi edinip nasıl anlamlandırdıklarını incelerler (22). Bu nedenle, nitel araştırma yöntemi araştırmamız içerisinde tercih edilmiştir. Katılımcıların 15'i kadın ve 5'i erkektir. Araştırma sürecinde gözleme dayanarak kumarhanelerde kumar oynayan erkek ve kadın sayısının hemen hemen eşit olduğu söylenebilir. Katılımcıların yaş ortalaması 50'dir. Örneklemin yaş ortalamasına bakıldığında, katılımcıların büyük bir kısmının orta yaş ve üstü olduğu anlaşılmaktadır. 
Katılımcılara kartopu örnekleme tekniği ile ulaşılımıştır. İlk katılımcıyla bir tanıdık aracılığıyla görüşme yapıldıktan sonra ilk katılımıının ve aracının yardımıyla diğer katılımcılarla görüşülmüştür. Katılımcıların çoğunluğu ile farklı kumarhanelerde, bazı katılımcılar ile de katılımcıların evlerinde görüşülmüştür. Görüşmelerde bilgi kaybının olmaması için katılımcıların da izniyle ses kayıt cihazı ile görüşmeler kaydedilmiştir.

\section{Veri Analizi}

Bu araştırmada verilerin analizi betimsel analiz türünde yapılmıştır. Verilerin analizi için öncelikle görüşmelerdeki kayıtlar kodlanmıştır. Analiz kodlaması cümle ve paragraf bazı olarak araştırmacı tarafından gerçekleştirilmiştir. Ayrıca, Kuzey Kıbrıs Türk Cumhuriyeti yasalarına göre, KKTC vatandaşlarının kumarhanelere girmeleri yasaktır. Buna rağmen, katılımcıların hepsi KKTC vatandaşıdır. Bu araştırma KKTC'de yaşayan kumarcıların görüşleriyle sınırlandırılmıştır.

\section{Bulgular}

\section{Kıbrıs Kültüründe Kumar}

KKTC'de kumar kültürü incelendiğinde özellikle "tombala" oyununun popülerliği dikkat çekmektedir. İngiltere'de özellikle yaşlılar arasında oynanan "Bingo" oyunun bir tür uyarlaması olan tombala, Kıbrıs adasının İngiltere himayesi altında olduğu süreçte (1878-1960) yaygınlaştığı öne sürülmektedir. Özellikle 1960'larla birlikte sinemalarda ve çeşitli yerlerde tombala oynanması oldukça yaygın bir eğlence haline gelmiştir. Kıbrıs Türk toplumu içinde "tombalanın" oldukça önemli bir yeri olduğu anlaşılmaktadır. Bu konuda bazı katıımcıların ifadeleri bu durumu açılamaktadır:

Bizim sinema zevkimiz vardı. Sinemaya gitmesek olmazdı. Tombala bir gelenekti sinemalarda. 1960lardan beri tombala oynanır Limasolda. Şahin sineması vardı, Taksim sineması vardı. Sinemada arada tombala oynanırdı. Kadınlar matinesi vardı. Çarşamba günleri sinema bedavaydı tombala için gelinirdi. Güzel bir şeydi. Ben 0 zaman nişanlıydım. Alırdım nişanlımı giderdim sinemaya. Başka eğlencemiz yoktu. (Erkek, Emekli Tekniker, 77 yaşinda).

Tombalalar önceden şöyle oynanırdı eskiden kulüplerde oynanırdı. Neden? Onlar bir ek gelirdi. Kulüplerde tombalalar kurulurdu, sandalyeler falan. Bu Kıbrıslıara özgüydü. Bu 74'den öncede vardı. Bunu da Rumlar başlatmıştı. Büyük sendikalarda, bunlarda oynatıllardı. Türkler de böyle şeyler yoktu. Ben hatıllarım yeni gençlik. Giderdik tombala oynardık. Ha bu tombala da İngiltere'den örnektir. Ben İngiltere'ye gittiğim zamanda öyle yaşı insanlar gidip belli gecelerde oluyor tombala oynuyorlar (Erkek, Emekli Kumarhane İşletmecisi, 70 yaşında).

Biz tabi daha önce de Kıbrılılar kulüplerde oyun oynardık konken dediğimiz poker dediğimiz yani kâğıt oyunlarını kulüplerde oynardık. Kahvelerde başladı ilk (Erkek, Emekli Memur, 75 yaşında).

Bunun yanı sıra, Kıbrıslı Türkler tarafından birçok köy ve kasabada horoz dövüşleri için bahisler yapılmaktaydı. Çeşitli kulüplerde de kâğıt oyunları oynamak oldukça popülerdi. Bu süreçte sadece özel kulüplerde az sayıda kumar oynanmaktaydı. Günümüzdeki "kumarhane" anlayışı ancak 1980'li yıllardan itibaren oldukça az sayıda açılan kulüplerde başlamıştı. Bu konuda bir katılımcının ifadeleri bu durumu doğrulamaktadır:

1974'ten önce (Savaştan önce) Kıbrı'ta casino diye bir şey yoktu. Casinolar 1974'ten sonra başladıydı. Illk casino açııısı 86-87 yılları arasındadır. Hatta o zaman Türkiye'de de daha açımamıştı. Türkiye'de casinolar 90'ı yıllarda açıldıydı. Ben oraya gittim Lütfü Topal'ın (Kumarhaneler kralı olarak bilinen Türk işadamı) casinolarının kurulmasında da emeğim geçti benim (Erkek, Emekli Kumarhane Işletmecisi, 70 yaşında).

Kuzey Kıbrıs'taki kumar endüstrisinin gerçek anlamda ortaya çıkması 1997'de Türkiye'deki kumar yasağı ile birlikte kumarhanelerin KKTC'ye taşınması ile başlamıştır. Bu süreçte KKTC'de kumar, sosyalleşme amacıyla maddi kaygısı olmayan bir eğlence türünden Las Vegas kumarhane modeli örnek alınarak 
yaratılan ve büyük paraların döndüğü modern kumarhane sektörüne ait ticarileşmiş bir endüstriye dönüşmüştür.

\section{Bir Alt Kültür olarak Kumarcılar}

Alt kültür benzer değerleri paylaşan bireylerin sosyalleşme sürecinde meydana getirdikleri kültürel değerlerden oluşan bir yapıdır. Bu çalışmada açıklanacağı üzere, Kıbrıs Türk toplumunda kumarcılar bir alt kültürdür. Bu alt kültürdekiler benzer değerlere ve davranış örüntülerine sahiptirler. Bu değerler ve davranışlar sosyalleşme süreçleri içerisinde şekillenmektedirler.

Alt kültürler, genelde yaşadıkları toplumun özelde ise ait oldukları toplumsal sınıfların kendilerine yansıyan olumsuzluklarına karşı birer tepki hareketi olarak ortaya çıkmaktadır. Bu durum toplumsal sınıftan toplumun bütününe ilişkin olarak kaygıları da bu çerçevede dile getirmiş olmaktadır. Örneğin Punklar, İngiltere'de "sadece artan işsizliğe, yoksulluğun artmasına, toplumsal depresyona doğrudan tepki göstermekle kalmıyordu. Aynı zamanda kesinlikle geçerli ve gerçekçi olan (...) rock kurumu retoriğinin karşıtı olan bir dili oluşturarak İngiltere'nin çöküşü olarak adlandırılan olguyu dramatize ediyorlardı (23). Bu bağlamda, 1974 yllında gerçekleşen savaş sonrası Kıbrıs Türk toplumunun siyasal, sosyal ve ekonomik boyutta izole bir yapı haline gelmesine bir de Türkiye'deki kumarhanelerin KKTC'ye taşınması eklenince kumar alt kültürünün oluşması kaçınılmazdır.

Bu çalışmada kumarın kumarcılar için anlamı, kumarhane rutinleri (kumarhaneya ne kadar sıklıkla gittikleri, kimlerle gittikleri, hangi kumar türlerini oynadıkları, kumardaki batıl inançları) ve kumarcıların hayalleri analiz edilmiştir.

\section{Kumarcılar için Kumar Ne İade Eder?}

Kumarın kumarcıların için ne ifade ettiğini anlamak kumar bağımlılı̆ı sorununu anlamak ve analiz etmek için önemlidir. Toplumdaki genel kanı (24), bireylerin para kazanmak amaçlı kumar oynadığı yönündedir. Toplumdaki genel kanının doğruluğunu sorgulamak için katılımcılara "kumarın onlar için ne ifade ettiği" ve "kumar oynarken nasıl hissettikleri" soruları sorulmuştur:

Kafamı dinliyorum. Bütün dertlerden temizleniyorum. Yani başka şey düşünmüyorum. Makinaya veriyorum kafamı. Hiçbir dert yok burada. Düşünecek bir şey yok. Aman verdi, aman vermedi... Bu şekilde oyalanıyoruz. (Amacınız rahatlamak mı?) Evet rahatlamak. Kimseyle konuşmuyorsun mesela, kafanı dinliyorsun. Sadece makineye veriyorsun kendini (Kadın, Emekli Fotoğrafçı, 80 yaşında).

Deşarj olmak, ne bileyim kafayı başka yerlere çevirmek anlamında. Bir şeye adapte olup da kafamı yormak istemiyorum. Onunla oyalanıyorum yani deşarj oluyorum. Rahatııorum (Kadın, Aşçı, 62 yaşında).

Zevk için. En fazla vereceği 100tl dir o da. Çok büyük oynayanlar var. 20 lira 20 lira basıyor parayı. Nerden buluyorlar bunlar parayı? Ben bilmem. Gerçekten de öyle. Adam atıyor 100 lirayı iki basmada bitiyor. Genelde Türkiyeliler. Biz Kıbrıslıarda nerde öyle para. Makinayı zevkine oynarız (Erkek, Emekli Esnaf, 70 yaşında).

Oyun oynarken bu yorgunluğu atıyorsun. Kafanda bir şeyler varsa düşünmüyorsun. Kafa doluysa, sorunun bir şeyin varsa orada yoktur. Oraya girip çıkana kadar yoktur. Kaybedersen çıktktan sonra daha çoktur (gülüşmeler) (Kadın, Emekli Mühendis, 50 yaş yaşında).

Katıımcıların ifadeleri toplumdaki para kazanmak amacıyla kumar oynandığı düşüncesini desteklememektedir. En azından birincil amaç bu değildir. Reith ve Dostoyevsky gibi benzer gözlemler, paranın kumar oynamanın gerekli bir unsuru olduğu ancak kazanmanın iddia edildiği gibi kumarcılar için birincil amaç olmadığını ifade etmektedirler $(25,26)$. Kumarcıların birincil amacı kumarın fenomenolojik hissini - onun vaadini - "oyunun süresiz devamı" yoluyla korumaktır. Oyun süresi içerisindeki "rahatlama" kumarcıların birincil amacı olarak görülmektedir.

\section{Kumarcıların Kumarhane Rutinleri}

Kumarcıların kumarhane rutinleri kumarcıların yaşamına dair birçok konuyu aydınlatmaktadır. Bu bağlamda katılımcılara "ne kadar sık kumarhaneye gittikleri", "kimlerle gittikleri", "hangi oyunları oynadıkları" ve 
"kumarda kazanmak için uğurlu olduğuna inandıkları şeyler olup olmadığı" soruları sorulmuştur. Katılımcılara ilk olarak "kumarhaneye ne kadar sıklıkla gittikleri" sorulmuştur. Bazı katıımcıların ifadeleri şu şekildedir:

Haftanın üç günü, dört günü burdayım (Kadın, Muhasebeci, 55 yaşında).

Her gün giderim (Kadın, Emekli, 73 yaşında).

Illk dört sene hemen hemen her gün gittim. Hasta olmadığım, misafirin gelmediği ya da Türkiye'ye gitmediğim sürece hemen hemen her gün gittim. Sonra çocuklar evlendi, torun oldu, 0 beni bağlamaya başladı. Bazen özellikle gitmiyim diye torunlarımı istiyorum yanıma haftasonu (Kadın, Evhanımı, 65 yaşında).

Haftada bir gün ya da iki gün. Özellikle makinalara çok sık gitmeyiz. Tombala için gideriz. Oraya gidince makine oynarsak o kadar. İki gün tombala var. Salı Perşembe (Erkek, Emekli Tekniker, 77 yaşında).

Katıımcıların ifadelerinden anlaşılacağı üzere, birçok kumarcı kumarhaneye düzenli olarak gitmektedir. Burada dikkat çeken iki nokta bulunmaktadır. Birincisi, özellikle emekliler ya da çalışanlar kumarhane yaşamını yaşamlarının merkezine koyarak kumarhanenin çevresinde hayatlarını şekillendirmektedirler. Ancak sosyal anlamda onları oyalayacak bir durum söz konusu olursa, kumarhaneye gitme sıklıkları azalmaktadır. İkincisi ise katılımcıların Kıbrıs toplumunun vazgeçilmezi olan tombala seanslarını çok önemli bir işleri olmadığı sürece kaçırmamalarıdır. Dolayısıyla günümüzde de tombala seansları bireylerin birbirleri ile görüştükleri, sohbet ettikleri ve eğlendikleri bir ortam özelliğini sürdürmektedir.

Katıımcılara sosyalleşme süreçlerini nasıl idame ettiklerini anlamak amacıyla katılımcılara kumarhaneye "kimlerle gittikleri" sorusu sorulmuştur. Bazı katılımcıların ifadeleri şu şekildedir:

Arkadaşlarla (Kadın, Emekli Fotoğrafçı, 80 yaşında).

Genelde ben yalnız geliyorum. Burada arkadaşlarla görüşüyoruz (Kadın, Aşçı, 62 yaşında).

Arkadaşlarla. Hepsi emekliler (Kadın, Evhanımı, 50 yaşında).

Ben genelde tek giderim. Ben fazla sevmem. Ama orda gelirler buluşurlar ama genelde ben sevmem. Ben birini alıp da casinoya götürmem (Erkek, Emekli Kumarhane Işletmecisi, 70 yaşında).

Katıımcıların \%90'ı kumarhaneye arkadaşlarıyla gittiklerini ya da arkadaşları ile orada buluştuklarını ifade etmişlerdir. Bu durum aslında kumarcıların kumarı bir nevi sosyalleşme aracı olarak gördügünü göstermektedir. Araştırma sürecinde katılımcılar 1974'teki siyasi durum ile birlikte Kuzey Kıbrıs'ta farklı bölgelerine yerleştirilmelerinin Kıbrıs toplumunda önceden çok yaygın olan komşuluk ilişkilerinin yok ettiğini savunmuşlardır. Katılımcıların ifadelerinden kumarcıların "kumarhane yaşamını" hayatlarında eksik olan komşuluk ve arkadaşlık ilişkilerinin yerine koydukları anlaşılmaktadır.

Katılımcıların kumarhane rutinleri içerisinde dikkat çeken bir diğer nokta da hangi oyunları oynadıklarıdır. Kumarhanelerde oynanan oyunlar tombala dışında canlı oyunlar ve makine oyunları olmak üzere ikiye ayrlır. Canlı oyunlar rulet, poker, blackjack vb. oyunlardır ve bu oyunlar genellikle yüksek paralar karşılığında oynanan oyunlardır. Makine oyunları ise makinadan makinaya değişmekle birlikte canlı oyunlara göre daha düşük paralarla oynanabilen oyunlardır. Çok fazla çeşidi bulunmaktadır ve teknolojik gelişmelere paralel olarak belli aralıklara yenilenmektedir. Bu bağlamda, katılımcılara üçüncü olarak, kumarhanede "hangi oyunları" oynadıkları sorusu sorulmuştur. Bazı katılımcıların ifadeleri şu şekildedir:

Genelde hepsini oynuyorum (makine). Canlıya asla oturmadım (Kadın, Emekli Mühendis, 50 yaş yaşında).

Daha çok bingo oynuyorum (makinada). Canlı şimdilik olmadığı için burada. Canlıyı (oyunu) zaten 6-7 senedir bıraktım. Önceden poker oynuyordum (Kadın, Esnaf, 62 yaşında).

Tombala arada makine (Erkek, Emekli Memur, 70 yaşında).

Ben her tür oyunu oynarım. Makine da oynarım, ruleti de oynarım, pokeri de oynarım (Erkek, Emekli Esnaf, 75 yaşında).

Katıımcıların \%80'i sadece makine oyunu ve tombala oynadığını ifade etmiştir. Canlı oyunlar genellikle yüksek para ile oynandığı ve daha çok uzmanlık gerektirdiği için katılımcıların çoğunluğu makinaları ve 
tombalayı tercih etmektedir. Canlı oyunları ise daha çok Türkiye'den gelen kumarcıların tercih ettiği dikkat çekmektedir. Sadece hafta sonları ya da haftalık Türkiye'den gelen kumarcıların sayısı azımsanmayacak kadar çoktur.

Kumar konusunda yapılan çalışmalarda kumarcıların batıl inançları pek ilgi görmüş olmasa da bu konu kumarhane yaşamlarının gözlemlemesi sürecinde oldukça dikkat çekicidir. Bâtıl davranışlar genellikle bâtıl bir inanç veya kabulün sonrasında gerçekleşir. Örneğin tahtaya vurarak, muhtemel bir zarardan kurtulacağını düşünen insan, bu düşünceye bağlı olarak tahtaya vurur. Zaman zaman birey belirli bir bâtı düşünceye sahip olmadan da bilinçsizce ve alışkanlık halinde bâtıl denilen davranışlar sergileyebilir. Bâtıl inanç ve davranışları bir bütün olarak değerlendirdiğimizde, bunların duygusal, bilişsel ve davranışsal unsurların bir araya gelen bir bütün olduğu görülmektedir. Bu bağlamda katılımcılara "kumarda uğur getirdiğine inandığınız bir inancınız var mı?" sorusu sorulmuştur. Bazı katılımcıların ifadeleri dikkat çekmektedir:

Taşıdı̆ı̆ım uğurlu bir şey yok. Ama bazen diyorum Ayşe (arkadaşı)'nin gözü... (Gülüşmeler). Sadece şuna inanıyorum, kazandığım paradan arkadaşlara verdiğim zaman benim kısmetim gidiyor (Nazar değdiğine inanıyor). 0 yüzden şimdi kazanırsam kimseye para vermiyorum (Kadın, Emekli Fotoğrafçı, 80 yaşında).

Tabi. Enerjimle giderim. Güzel geçecek diye giderim. Alacam diye çok hırs yapmam ya da aman verecem değil. Hissederim yani. Rakamlara inanııım. 0 rakamların bana geleceğine inanırım. Kitaplar (makina oyunu) beni çok sever. Beyin gücü... Çağırıyorsun ve geliyor diye düşünüyorum. Bingo da 9 ve 7 rakamlarına çok inanııım. Genelde o rakamları tutarım (Kadın, Evhanımı, 61 yaşında).

Zeytin ağaçlarından zeytin koparıyoruz (gülüşmeler)... Zeytin uğur getiriyor diye. Ama 0 da olmuyor. İnancım var ona (Erkek, Emekli Tekniker, 77 yaşında).

Vallahi benim öyle şeylerim yok şans getirdiğine dair. İnsanoğlunun belirli dönemlerde belli bir şansı var. Kumar oynamayan insan için de bu geçerlidir. Kumar başka bir şey siz bilmediğiniz için onu anlayamazsınız. Kumar nedir? Kumar "feeling (his)"dir. Mesela gidiyorsunuz ruletin karşısına geçtiniz. İ̧inizden 17 numara gelecek dersiniz. Peki dersiniz ona basarsınız fişinizi. Küt 17 diye gelir. Eğer şanslıysanız her şeyde eliniz doğru yere gider. Şansızsanız ne yapsanız da oyun gelmez yani. Benim tecrübelerim onu gösterir (Erkek, Emekli Kumarhane İsiletmecisi, 70 yaşında).

Kumarda batıl inanç konusu katılımcılar arasında farklı görüşlere neden olmaktadır. Kimi katıımcılar bazı şeylerin uğur getirdiğine inanırken diğer katılımcılar kumarda uğur getirmenin söz konusu olmadığını savunmaktadırlar. Kumarcılar arasında yaygın olan batı inançlar şunlardır: Zeytin ağacına dokunmak, zeytin koparmak ve çeşitli eşyaların uğur getirdiğine inanılmasıdır. Bunun yanı sıra kumarhaneye pozitif enerjiyle gitmek ve negatif enerjiden sakınmak diğer batı inançlardan bazılarıdır. Özellikle en yaygın olan batıl inançlardan biri kumarcıların "nazar"dan korkmasıdır. Bu nedenle de genellikle kumarcılar kumar oynarken yakınlarında pek kimseyi istemezler.

\section{Kumarcıların Hayalleri}

Daha önce de değindiğimiz gibi, toplumdaki genel kanı bireylerin kumarı para kazanmak amacıyla oynadıkları doğrultusundadır. Ancak katıımcıların ifadeleri para kazanmanın birincil amaç olmadığını göstermektedir. Bunu teyit etmek amacıyla katılımcılara

"Hayalinizde kumardan ne kadar para kazanmak var ve bu parayla ne yapmayı planlıyorsunuz?" soruları sorulmuştur. Bazı katılımcıların ifadeleri şu şekildedir:

Yoktur çünkü kumardan para kazanmam bilirim. Çok çok kazanacağım 500 tldir bilirim. Onunla da hiçbir şey yapamam zaten. Onunla tekrar giderim oyuna çünkü emekli maaşım ancak da yeter ben hayatımdan memnunum. Yani kimseye borcum yok intiyacım yok. Öyle keyif çatıyorum. Zaten bu saatten sonra ne yapıcam (Kadın, Emekli, 70 yaşında).

Yok hiç olmadı, olmaz da. Kumardan kimse köşe olmamış. Abim kumarda koca çiftliği batırdı. Onun için biliyorum kumardan kimse köșe olmaz. Zararım yok diyorum, ona rağmen vardır yine. Çünkü her gün geliyorum. Alıyorum mesela dün ve evvelsi gün aldım. Bunları haftaya çevirdiğin zaman kar gibi görünüyor ama hiçbir zaman kumar kazandırmaz. (Kadın, Aş̧̧ı, 62 yaşında). 
Hiç düşünmedim. Milli piyangodan düşündüm çünkü 0 büyük bir meblağ. Ne kadar kazanabilirim ki casinoda? Çünkü büyük oyuncu değilim ki. Kazansam 20 bin tl kazanırım en fazla. 20 bin tl işimizi görmez ki. Şu anda bir evim yok milli piyangodan kazansam bir ev alırım. Çocuklarıma birer araba alırım. Buradaki oyunda yok öyle bir şey. Ben küçük oyuncu olduğum için olmaz yani. Yılbaşında jackpot attı birine 1 trilyon kazandı makinadan. Ama büyük oyuncuydu. Tabi her gün gel her gün gel bitirdi o parayı (Kadın, Evhanımı, 61 yaşında).

Benim hiç olmadı çünkü kumardan kazanmayı bekleyen çok yanııır. Yok böyle bir dünya. Kazanmazsın yani. Kumarcı bugün kazanabilir. Sonuna baktı̆̆ın zaman bilecen ki onun hayatı bitmiştir. Yani büyük kumar oynayanlar için söylüyorum bunu. Türkiye'de görürsen kaç tane battı kumardan battı. En büyüğünden en küçüğüne kadar... Kumardan kazanan olmaz (Erkek, Emekli Kumarhane Işletmecisi, 70 yaşında).

Katılımcıların kumarla ilgili ifadeleri ve özellikle kumardan para kazanılmayacağına dair olumsuz inançları oldukça dikkat çekicidir. Milli piyango ve benzeri şans oyunlarını oynayanlardan farklı olarak kumarhanedeki kumarcılar kumar olgusuna daha realistik yaklaşmaktadırlar. Kendilerinin küçük oyuncu olduğunu, büyük miktarlarda para kazanamayacaklarını veya kazansalar bile sürekli oynadıkları için bu paranın da biteceğinin farkındadırlar. Bu farkındalıkla birlikte kumarcıların asıl amacının yüksek meblağlarda para kazanmak değil kumar oynama süreci içerisinde "rahatlama, haz arama ve zevk alma" olduğu açıkça görülmektedir.

\section{Tartışma}

Literatürde kumar konusunda yapılan çalısmalar $(20,21)$ kumar oynanan yerlerin bireyler için öncelikle bir sosyalleşme mekânı olduğu ve bahis oynamanın kazanç beklentisi ile hayata heyecan katma gibi intiyaçların karşılanmasının da bir yolu olabileceği sonucuna varmışlardır. Bu çalışma da bu sonucu destekleyerek şunu eklemektedir: Toplumdaki genel kanının aksine kumarcılar için kumarın anlamı öncelikle "zevk alma ve rahatlama"dır. Para kazanma isteği ikinci ya da üçüncü amaç olarak görülmektedir. Bunun yanı sıra, para kazanmak oyununun süresini uzatması yani hazzın devamının sağlaması açısından önemlidir.

Kumar alanında yapılan çalışmalarda görülen önemli bir eksiklik ise kumarın tarihsel boyutu ve alt kültürel bir yapı olarak kumarcıların yaşamının incelenmesidir. Bu çalışma ile bu eksiklik giderilmeye çalışılmıştır. Araştırmadan elde edilen sonuçlar kısaca şu şekilde özetlenebilir: IIlk olarak, Kıbrıs toplumunda kumar alt kültürü, 1974 yllında Kıbrıs adasına gerçekleşen müdahale sonrasında gelişen siyasi, sosyal ve ekonomik duruma ve 1997 ylında Türkiye'deki kumarhanelerin kapanıp KKTC'ye taşınmasına bir tepki olarak ortaya çıkmışıır.

İkinci olarak, katılımcılar ikinci seviye- kumar oynamaya bağı bazı problemler yaşamaya başlayanlar ile üçüncü seviye- kumar oynamaya bağlı ciddi sorunlar yaşamaya başlayan kumarcılardır. Katılımcıların kumarhaneye gitme sıklıkları ve kumara bağlı olarak yaşadıkları problemlerden bu durum açıkça anlaşılmaktadır. Dolayısıyla Kıbrıs Türk toplumunda kumar oynama davranışı sosyalleşme ve eğlenme amacıyla yapılan bir etkinlik olmanın çok ötesine geçerek kumar bağımlı̆̆ının ileri aşamalarına gelmiştir. KKTC'nin siyasi, sosyal ve ekonomik yapısı bu sürecin şekillenmesindeki en önemli unsurdur.

Araştırmamızın başlıca kısıt|lığı katııımcı olarak daha çok orta yaş ve üstüne ulaşılmasıdır. KKTC'de yaşayan gençlerin kumar alt kültürü konusundaki görüşlerine yer verilememiştir. Bu durumda araştırmada farkı bakış açılarının dahil edilmesinde eksikliğe neden olmuştur.

Sonuç olarak, Kıbrıs Türk toplumunda bireylerin sosyal ve ekonomik hayatlarını canlandıracak faaliyetlerin yapııması bireylerin kumar bağımlıı̆ından uzak kalmasını sağlaması yönünden atılabilecek önemli adımlardır. Bu araştırma sadece Kıbrıs Türk toplumundaki kumar bağımılığını analiz etmiş̧tir. Araştırma süreci içerisinde en büyük zorluk birçok katıımcının kumar oynadığını kabul etmemesi ve bu nedenle de görüşme yapmak istememesinden kaynaklanmışır. Ancak güven ilişkisi sağlandıktan sonra bu katılımcılarla görüşme sağlanabilmiştir. Gelecekteki çalışmalar için Kıbrıs Türk toplumundaki diğer bağımlılık türlerinin de araştıııması konuya kapsamlı bir bakış açısı sunacaktır. 


\section{Kaynaklar}

1. Dinç M. Eylemsel bir bağımllık: Kumar. Yesilay Dergisi 2014; 967: 20-23.

2. Lesieur HR, Blume SB. The South Oaks Gambling Screen (SOGS): A new instrument for the identification of pathological gamblers. Am J Psychiatry 1987; 144(9): 1184-1188.

3. Nower L, Blaszczynski A. Gambling motivations, money-limiting strategies, and precommitment preferences of problem versus non-problem gamblers. J Gambl Stud 2010; 26(3): 361-372.

4. Clark L. Disordered gambling: the evolving concept of behavioral addiction. Ann N Y Acad Sci 2014; 1327(1): 46-61.

5. Çakıcı M, Çakıcı E, Karaaziz M, et al. KKTC'de kumar yaygınlığı, risk etkenleri ve kültür tutumları ile ilişkisi: 2007-2014. Anadolu Psikiyatri Derg 2019; 20(4): 395-403.

6. Murray GF. The cannabis-cocaine connection: A comparative study of use and users. J Drug Issues 1984; 14(4): 665-675.

7. Smart RG, Ogborne AC. Drug use and drinking among students in 36 countries. Addict Behav 2000; 25(3): 455-460.

8. Pedersen W. Cannabis use: Subcultural opposition or social marginality? A population-based longitudinal study. Acta Sociol 2009; 52(2): 135-148.

9. Mjaland K. A culture of sharing: Drug exchange in a Norwegian prison. Punishm Soc 2014; 16(3): 336-352.

10. Vondrackova P, Gabrhelik R. Prevention of internet addiction: A systematic review. J Behav Addict 2016; 5(4): 568-579.

11. Zajac K, Ginley MK, Chang R, et al. Treatments for internet gaming disorder and Internet addiction: A systematic review. Psychol Addict Behav 2017; 31(8): 979-994.

12. Neverkovich SD, Bubnova IS, Kosarenko NN, et al. Students' internet addiction: Study and prevention. Eurasia Journal of Mathematics, Science and Technology Education 2018; 14(4): 1483-1495.

13. Devereux EC. Gambling and the Social Structure: A Sociological Study of Lotteries and Horse Racing in Contemporary America. London: Ayer Co Press, 1980.

14. Lesieur HR. The Chase: Career of the Compulsive Gambler. Massachussets, MA: Anchor Press, 1977.

15. Livingston J. Compulsive Gamblers: Observations on Action and Abstinence. New York: Harper Row Press, 1974.

16. Preston FW, Shapiro PD, Keene JR. Successful aging and gambling: Predictors of gambling risk among older adults in Las Vegas. Am Behav Sci 2007; 51(1): 102-121.

17. Kalischuk RG. Cocreating life pathways: Problem gambling and its impact on families. Fam J Alex Va 2010; 18(1): 7-17.

18. Binde P. Preventing and responding to gambling-related harm and crime in the workplace. Nordic Studies on Alcohol and Drugs 2016; 33(3): 247-266.

19. Salonen AH, Hellman M, Latvala T, et al. Gambling participation, gambling habits, gambling-related harm, and opinions on gambling advertising in Finland in 2016. Nordic Studies on Alcohol and Drugs 2018; 35(3): 215234.

20. Sağır A, Çabuk S. Şans oyunlarının toplumun beklentileri üzerine etkisi: Sakarya örneği. Sakarya Üniversitesi Fen Edebiyat Dergisi 2010; 12(1): 143-166.

21. Üstün A. At yarışı oynayanların sosyalleşme deneyimleri. V. Türkiye Lisansüstü Çalışmaları Kongresi - Bildiriler Kitabı I. 2016.

22. Berg BL, Lune H. Sosyal Bilimlerde Nitel Araş̦tıma Yöntemleri. Konya: Eğitim Yayınevi, 2019.

23. Hebdige D, Tarım E. Gençlik ve Altkültürleri. İstanbul: İletişim Yayınevi, 1988.

24. Griffiths MD. The cognitive psychology of gambling. J Gambl Stud. 1990; 6(1): 31-42.

25. Reith G. The Age of Chance: Gambling in Western culture. London: Psychology Press, 2002.

26. Dostoyevsky F. The Gambler. London: Hesperus Press, 2015. 